\title{
ITINERARIES BEYOND TOURISM: experiences with a local community in Petrolândia-PE
}

\author{
Paulo Henrique Ferreira Lacerda \\ Ranieryson Viana de Freitas ${ }^{b}$ \\ Ilana Barreto Kiyotanic
}

\begin{abstract}
The involvement of the local community is one of the main bases of support for the tourist development of localities, especially for small municipalities, where the lack of engagement of the population may be more keenly felt. One such case is Petrolândia, a small municipality in the sertão (semi-arid mountain range) of Pernambuco, where tourism is on the increase, but where attempts to raise awareness of tourism among the local community have been ineffective. In an action carried out with the municipal government, this work describes the experience of a pilot project applied in the community to promote the appreciation of the local culture and generate knowledge through tourism. The methodologies adopted by the pilot project involved tourist trips to local attractions and the application of questionnaires to the participants. The results, based on a qualitative approach, show that the action contributed to tourist awareness and helped strengthen relations between the local community and tourism. The action can also be an alternative for the municipal public planning of tourism and a tool for heritage education and tourist awareness.
\end{abstract}

\section{Keywords:}

Raising awareness of tourism

Historical-cultural routes

Local community

Petrolândia-PE 


\section{INTRODUCTION}

The inclusion of the host population is an essential part of tourism planning that seeks local development and sustainability (Hall, 2001). For this reason, the institutional scenario of national tourism policies has been seeking to promote a collaborative, decentralized, and participatory work for around twentyfive years (Endres, 2008), attempting to give civil society a more active role in view of the dominant logics (Oliveira, 2005). However, the prevalent models of tourism planning, especially in "underdeveloped" destinations, have contributed to the creation of more processes of exclusion, with planning models that focus largely on the tourists, while neglecting the needs of the local population.

According to IBGE Cidades, the municipality of Petrolândia is located in the Sertão Itaparica region of Pernambuco, and has approximately thirty-nine thousand inhabitants. It is about $430 \mathrm{~km}$ from Recife, the state capital (IBGE, 2018). The municipality has been featured on the covers of national magazines, such as edition 73 of Azul Magazine, and also on television, in the national open media, with reports in the TV program Fantástico about the submerged church, one of the main attractions of the area. The municipality has a Tourism Action Plan, through its Municipal Secretariat for Tourism and Economic Development.

This case report describes a pilot project aimed at developing alternative ways of promoting appreciation of the local culture and generating knowledge through tourism. The method adopted was to conduct trips to the city's tourist routes by visiting the local attractions with the community, based on the view that these routes should be able to not only systematize the tourist offer, but also serve as leisure opportunities for the local population.

In the section Problem and Relevance section, this work addresses the reasons why this report of experience is important for tourism and the local community. Next, the Methodology presents the methodological positioning of the action, the steps taken, and the procedures used. In the Results, the experience is explained, and in the final section, the Conclusion, the repercussions of the experience are presented.

\section{PROBLEM AND RELEVANCE}

First, it should be pointed out that the main area of tourism investment by the municipality of Petrolândia (PE) is the Itaparica Lake and its attractions. This lake was created for the construction of the Luiz Gonzaga Hydroelectric Dam, flooding the former administrative headquarters of the municipal- ity, in 1988. The population was relocated to another space, creating a new city, which is now thirty-two years old, but at that time, it had already existed for seventy-nine years. Naturally, this created a fissure in the lives of the population, altering the living space of the population. The change in territory represented the biggest transformation in urban and rural patterns in the history of the municipality, bringing drastic changes in the social, cultural, spatial, and economic relations that had not been seen in the region since the 18th century, when the human settlement of the region first began (Santos, 2019).

Around $51 \%$ of the municipal population in 2021 were born after the flooding of the old city (IBGE, 2017). This fact is notable because it means that the socio-spatial construction of the city is comprised of children, young people, and young adults who have no experience or understanding of the history of the municipality prior to 1988, making it a population that only partially retains the memory of Petrolândia from the former days, now submerged in the lake forms the backdrop to the present-day city.

The Petrolândia Tourism Action Plan, elaborated by the SEBRAE-PE, aims to: "Promote tourist activity in the municipality in a structured way, consolidating tourism as a source of employment, occupation, and income for the population" (p. 4). However, although the local population is a target of its actions, and is affected by the possible repercussions of tourism in the municipality, actions to promote tourism awareness have focused on the tourist trade, rather than on working with the general population (SEBRAE, 2018).

Tourism awareness programs give communities the opportunity to ask questions about tourism, and simply to be persuaded. That is why it is important to work with a critical and realistic view of tourism, knowing what the community wants most, and respecting the local dynamics. When organized in accordance with the local reality, awareness programs can provide ways to involve the local community and give them a leading role in the destination (Hanai \& Espíndola, 2011).

Given this context, it is necessary to discuss and analyze which methodologies are capable of putting the community in contact with its location in a way that respects its particularities and conditions, allowing its members to see tourism as a beneficial activity rather than as a source of spatial and social segregation. Therefore, even faced with an institutionalized scenario of spaces of planning and participation, transfers of resources to the tourism sector, spontaneous media for publicizing the municipality, and attractions that stand out in the Brazilian Semi-arid regions, there are some factors that pose barriers strengthening relations between the community and tourism, such as the lack of actions to raise tourism awareness.

With this perspective, the questions are asked: How can we encourage community interaction with the 
tourist attractions of its municipality and part of its history? Is it possible to create an efficient tourist awareness that respects local conditions?

\section{METHODOLOGY}

Bibliographic research was carried out to gain an initial understanding and form a basis for the construction of this work. We searched for articles, books, and magazines that dealt with the subjects: public policies, participation, heritage, and tourism awareness, which guided the actions and theoretical constructions for the pilot project. The experiences were composed of visits to three local attractions, guided by members of traditional communities, at no cost to the participants, with moments of interaction, and the application of action questionnaires at the end of the activity. As a target audience, through the partnership with Casa das Juventudes, and based on the understanding that young people become opinion multipliers, not only within their communities but also because they share their experiences through the social media, the action was attended by forty-five young people from the municipality.

The aim of the questionnaires was to determine the participant's prior knowledge (or lack of knowledge) about the places visited, their satisfaction with the visit, whether they had already visited the attraction, whether they would take a tourist to this place, and finally, their understanding of how tourism occurs in the city. The project was approved by the Casa das Juventudes coordinator, and was carried out in the last weekend of January 2019. There were forty respondents, registered and participating in the Casa das Juventudes Program. Informal conversations with the young people were also held, seeking their views and feedback on the activities.

The three attractions visited were chosen because they are part of the tourist routes most marketed by the local tourism industry, because they are organized by traditional communities, and because they represent strategic places that tell about the past and recent history of the municipality.

\section{RESULTS}

The Casa das Juventudes Program was created in 2011, by Pernambuco State Law 14,577/2011, and is an institutional space of reference for Young people (Law n014.577/2011, December 28, 2011). This action by the Pernambuco Department of Children and Youth, carried out in partnership with the municipalities, aims to offer a physical space to welcome members of the community in situations of socioeconomic vulnerability, giving them contact with politics, technology, lei- sure, and the city to which they are entitled.

Following a request to the Casa das Juventudes to adapt its holiday camp schedule, a pilot project was made viable through the support of the municipal government and its Municipal Secretariat for Social Development, which provided the resources to carry out the proposed experiences. The Casa das Juventudes holiday camp schedule always gives young people contact with private leisure facilities in the city; however, the action taken aimed to make new spaces of the holiday camp public, especially those visited by tourists, i.e., the city's tourist attractions.

The attractions were strategically chosen because they were not part of the young peoples' daily lives, their experience being mostly limited to the urban context. The attractions were:

- $\quad$ The Serrote do Padre ecological trail (Figure 1). This trail is in a rural area of the municipality and is part of the Pankararu indigenous reserve. It was used to tell the story of the town and the region, through community-based ecotourism, led by members of the indigenous territory.

Figure 1 - View from Serrote do Padre

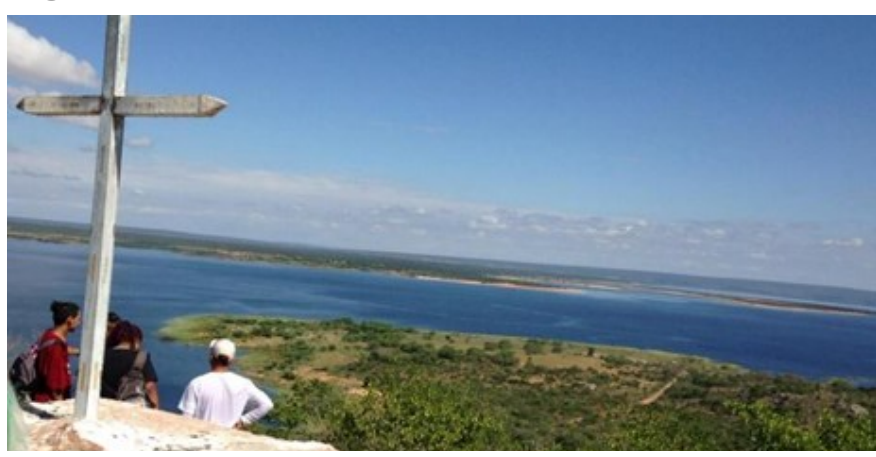

Source: The Authors, 2020

- A visit to the Angico Village (Figure 2). Home to a different tribe, but also belonging to the Pankararu peoples, the Angico Village community told the story of its struggle for territory, as yet unlegalized, and

Figure 2 - Visit to Angico Village

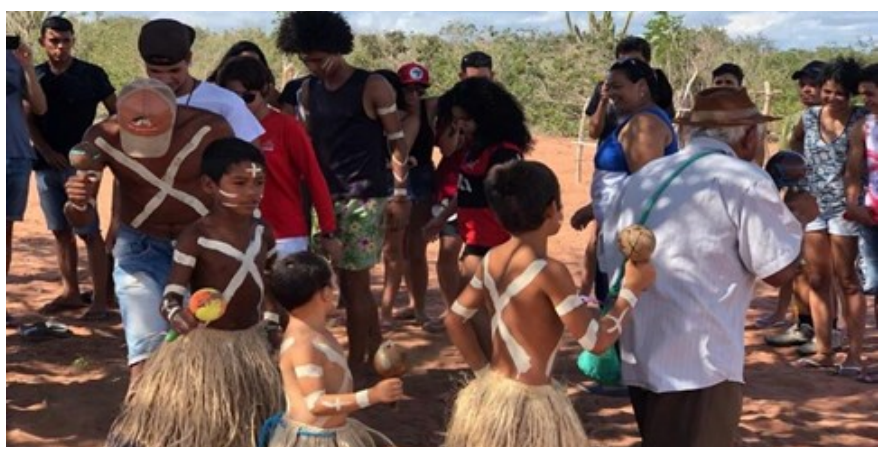

Source: The Authors, 2020 
displayed its culture through music, dance, clothing, painting, and oral history. The village is in a rural area of the municipality.

- A visit to Bico do Papagaio (Figure 3). The last destination was chosen for its natural beauty, as recently highlighted in the digital media, a popular destination with tourists, and because it was organized by the families that first settled in the rural area of the new headquarters of the municipality.

Figure 3 - Visit to Bico do Papagaio

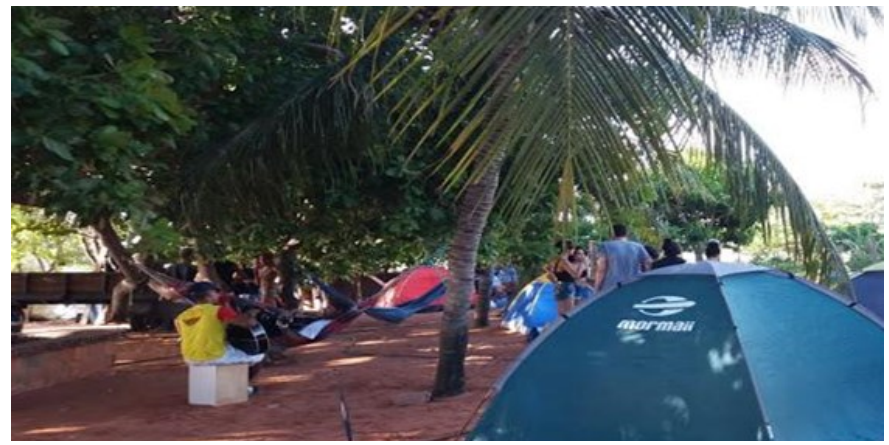

Source: The Authors, 2020

The Serrote do Padre trail, on day 1, enabled the young people to interact with the local community. The trail was led by a local guide, who explained about the native fauna and flora, and told legends and stories of the local indigenous culture and the distant past of the ancestors who lived there. The trail was along an easy route and was completed in a few hours, with stop-offs for recreational activities, such as swimming in the river.

A highlight of the visit was the summit of the hill overlooking Lake Itaparica, where the old city once stood before it was flooded to make way for the hydroelectric dam. The panoramic view takes in the only building that remains standing, now partially submerged - the Sagrado Coração de Jesus church, located in the district of Barreiras. At this climactic point of the journey, visitors can also see the first Cross of the old city, where residents would visit on Holy Week for religious devotions, with a wooden cross marking the place for over a hundred years.

Also on day 1, the young people visited the Gruta do Padre (Cave of the Father). The place tells a remarkable story from the city's past, where a priest and a woman resident of the old municipality were killed. The story was well known to everyone in the old municipality, according to the local guide, yet $82 \%$ of the young people who took part in the visit had not heard of it. At the end of the activity, the participants were invited to discuss and ask questions about the importance of

\footnotetext{
${ }^{1}$ The toré is a traditional indigenous cultural manifestation that involves singing and dancing. It is performed in rituals with sacred, social, cultural, and political dimensions (Grünewald, 2008).
}

tourism for reviving the local history, the importance of passing down history, and the conflicts and legends of the city's indigenous tribes, under the leadership of the tour guide.

Day 2 was a trip to the Aldeia Angico. In order to provide cultural knowledge about the history of families living in the village, and the history of their struggle for indigenous territory over the past twenty years, the tour was conducted with the support of the indigenous secretary, representative of the indigenous struggles for territory in the municipality. The young people were able to experience daily life in the indigenous village, and through stories, learn about the changes that have taken place in the indigenous territory and what is happening now in this regard. They also learned about some songs and rituals of the community, participated in a toré ${ }^{7}$, made paintings, and talked with the tribal leaders about the struggle for territory, their history, and how they have kept their culture alive after the relocation of their living spaces and territory. The topic of tourism was brought up during the conversations, and one of the community leaders expressed that it is a good way to earn money, as most of the local community do not have regular jobs. Besides, acting as guides for visitors to the community during traditional celebrations was something they already did, and sometimes, they sold herbs and handicrafts made with natural products, as well as local produce. There is no good structure in the place; however, there is a seasonal flow of people during periods of celebrations and rituals, at least three times a year.

On day 3, the final day, the main purposes of the action was to develop the sociability of the young people, provide some leisure time, and stimulate and support cultural productions, such as poems and authorial songs. The young people took a guitar, music, stories, handicrafts, and poems of their own to the luau - held in the private lands of a family that owns an establishment selling food and drink near the village visited on day 2. The owners of the establishment also mentioned the importance of having a structure to receive visitors, and explained how they had lived in this rural part of the municipality since they arrived in 1987, surviving from fish farming, agriculture, and receiving visitors. The dialogical nature of the interactions between the young people and the local inhabitants are in line with what Hanai and Espíndola (2011) propose, highlighting the need to give the population an active role in the process of understanding tourist activity. Giving these young people experience of these host communities can stimulate interest in tourism, which would be beneficial, showing the repercussions of raising awareness of tourism.

Based on the results of the questionnaires, we found a high level of satisfaction and interest in the activities carried out, despite the fact that most of the young people were previous unaware of the places visited, as 
shown in Table 1.

Table 1: Responses to the questionnaires applied after the series of visits

\begin{tabular}{l|l}
\hline QUESTION & RESPONSE \\
\hline $\begin{array}{l}\text { Are you satisfied with the activities } \\
\text { we carried out? }\end{array}$ & YES- 100\% \\
NO- 0 \\
\hline $\begin{array}{l}\text { Would you go back to the places } \\
\text { we visited? }\end{array}$ & YES- 91\% \\
\hline $\begin{array}{l}\text { Were you able to answer your } \\
\text { questions about tourism? }\end{array}$ & YES- 100\% \\
\hline
\end{tabular}

Source: The Authors, 2020.

The satisfaction of the young people who visited these places was essential for ensuring another favorable condition for good tourist awareness, as well as the sense of knowing about tourism in that attraction. These responses, together with the possibility of returning to the place, can stimulate young people to play an active role, recommending the attractions to their families and friends, or even taking them there. This gives civil society a more proactive role in local tourism and can help reduce the marginalization of the communities that live in these places, as pointed out by Oliveira (2015).

Figure 4 - Young people's previous knowledge about the attractions visited

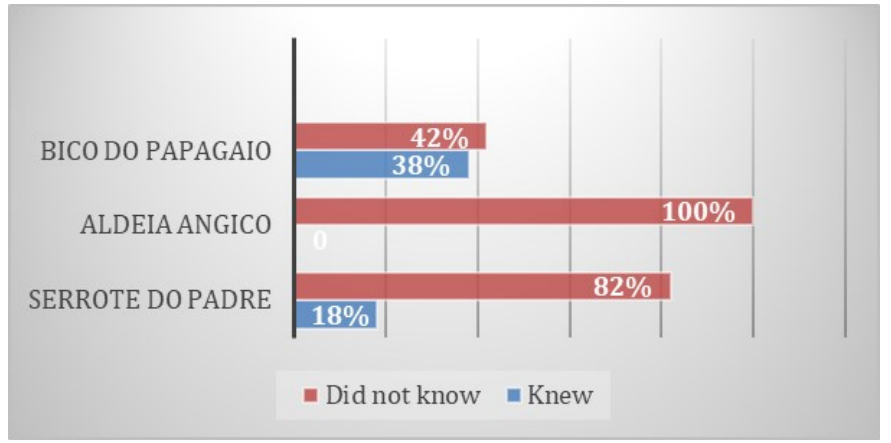

Source: The Authors, 2020

As mentioned above, according to data from the IBGE, about $51 \%$ of the city's present-day population was born and raised in the new city. This is clear from Figure 4, which also shows the distance between the young population and the spaces of historical and cultural representation in the municipality. The fact that very few of the young people knew about the places visited also suggests a need to incorporation local culture in the curricular activities of schools, and for other public sector mobilizations on the topic, such as tourist awareness or heritage education, as instruments for increasing knowledge of the local territory, valuing and preserving it and promoting social inclusion (Hanai \& Espíndola, 2011).

In the conversations, the young people showed curiosity about how to improve the infrastructure to receive tourists, explained the problems they had identified in the places visited, and talked about other spaces and actions with good tourist potential. The coordinator of the Casa das Juventudes and the student responsible for the action described the tourist inventory and tourism diagnosis in the municipality, talked about training opportunities that the municipality offers to the sector, and discussed the importance of these tourist places for bringing benefits to the population.

\section{PRACTICAL IMPLICATIONS AND CONCLUSIONS}

Tourism can promote much more than income for a community. Besides bringing economic benefits, the theory in this work applied in practice was able to verify that the activity can give the community greater engagement with its space, a greater sense of belonging, and a pride in its habitat and culture. Through the pilot project, it was possible to verify that inclusive tourism is a viable alternative. Working with tourism with the community, using the structures and spatial modifications caused by the activity, is a dynamic mechanism for community interaction with the local space.

It was noticed that there is little contact between the local community and the attractions, and between these young people and their history. The pilot project promoted these interactions, at different levels, bringing benefits for participants, as they got to know the local culture as well as gaining a better understanding of tourism. The action provided an opportunity for the young people to learn more about their history and culture. It was also possible to innovate in the actions of the Casa das Juventudes, which will now be able to benefit from structured actions in public places, saving resources and enabling the valorization of culture and territories of municipal historical-cultural value.

Tourist itineraries can serve as an additional patrimony for host communities, combining knowledge, teaching, culture, and environmental interaction. Through a systematization between tourist space and place for the community, it is possible to start a work of raising tourism awareness among the local population. The experience can also strengthen ties between young people from the city and local tourism, perhaps becoming a future program for raising tourist awareness or cultural appreciation of the municipality.

The contribution of the experience described here is its innovative nature and the way it aligns social, cultural, and management needs in a single solution, 
using commercialized spaces and structured by and for tourism.

There were some factors that limited the success of the action: the lack of signage for access to the attractions, the lack of information about the territory, and insufficient transportation to the attractions visited.

Subjects for future research may include the profile of young people, their knowledge of the local culture, and their distribution in the city in terms of where they live. Practically speaking, seeking to implement a series of actions to raise tourism awareness in the municipality will also be fundamental for tourism planning and local culture, as the action described here showed that the attractions are rooted the historical-cultural situation, but that many are unaware of this context.
Santos، C. C. (2019). Transformações das relações ruralurbano desencadeadas por grandes empreendimentos hidrelétricos: reflexões a partir de Petrolândia - PE. Retrieved from https:// attena.ufpe.br/bitstream/123456789/35680/1/ TESE\%20Cl\%c3\%a9lio\%20Cristiano\%20dos\% 20Santos.pdf. Accessed on: 02/02/2020.

SEBRAE. (2018) Plano de Ação do Turismo de Petrolândia-PE. Petrolândia, Pernambuco.

\section{REFERENCES}

Endres, A. V. (2008) Políticas de turismo, desenvolvimento e o papel do estado: cenários e inquietaç̃̃es. Em Tese, v. 5, n. 1, 74-97. Retrieved from <https://periodicos.ufsc.br/index.php/emtese/ article/view/18065023.2008v5n1p74\&gt> Accessed on: 08/04/2019.

Grünewald, R. A. (2008). Toré e Jurema: emblemas indígenas no Nordeste do Brasil. Ciência e Cultura, v. 60, n. 4, 43-45. Retrieved from <http:// cienciaecultura.bvs.br/scielo.php? script $=$ sci arttext\&pid $=$ S0009

67252008000400018>. Accessed on: 08/04/2020.

Hall, C. M. (2001). Planejamento turístico: políticas, processos e planejamentos. São Paulo: Contexto.

Hanai, F. Y. \& Espíndola, E.L. G. (2011). Programa de Sensibilização Sustentável do Turismo: uma proposta para envolvimento e participação de comunidades locais. Revista Turismo em Análise, v. 22, n. 1, p. 4-24. Retrieved from http:// www.periodicos.usp.br/rta/article/ view/14238/16056\&gt. Accessed on: 02/01/2019.

IBGE, Instituto Brasileiro de Geografia e Estatística. (2018). Cidades. Retrieved from https:// cidades.ibge.gov.br/brasil/pe/petrolandia/ panorama. Accessed on: 19/01/2019.

IBGE, Instituto Brasileiro de Geografia e Estatística. (2017). Monografias municipais: Nordeste/ Pernambuco -Petrolândia. Rio de Janeiro: IBGE.

Lei Ordinária $n^{0} 14.577 / 2011$. Dispõe sobre o programa Casa das Juventudes. Governo do Estado de Pernambuco. Retrieved from http:// legis.alepe.pe.gov.br/texto.aspx? id $=2680$ \&amp;tipo $=$ TEXTOORIGINAL. Accessed on: $23 / 02 / 2020$.

Oliveira, A. C. (2005). A atividade turística e seus efeitos à população local: um paradoxo. Caderno Virtual de Turismo, v. 5, n. 2, 73-87. Retrieved from https://www.redalyc.org/ pdf/1154/115416149006.pdf\&gt. Accessed on: $10 / 10 / 2019$ 